\title{
|| Eğitim Örgütlerinde İstismarcı Yönetim ve Örgütsel Öç Alma Davranışı Arasındaki ilişki
}

\author{
Pelin TAȘKIN*
}

Öz: Eğitim örgütlerinde istismarcı yönetim ve öç alma davranışı arasındaki ilişkiyi belirlemeyi amaçlayan bu çalışmada ilişkisel tarama modeli kullanılmıştır. Araştırmada İstismarcı Yönetim Ölçeği ve Örgütsel Öç Alma Ölçeği uygulanmıştır. Veriler 2017-2018 eğitim öğretim yılında Ankara kamu okullarında görevli 361 öğretmenden toplanmıştır. Bulgulara göre, erkek öğretmenler istismarcı yönetime ve örgütsel öç alma ölçeğinin davranışsal tepkiler boyutundaki ifadelere daha fazla katılım göstermişlerdir. Ayrıca, 0-10 yıl arası kıdeme sahip ve 21 yıl ve üzeri kıdeme sahip öğretmenlerin, 11-20 yıl arası kıdeme sahip öğretmenlere göre İstismarcı Yönetim Ölçeğinin ifadelerine daha fazla katılım gösterdikleri belirlenmiştir. Lisansüstü mezunu öğretmenler, lisans mezunu öğretmenlere göre öç alma nedenlerine ve davranışsal tepkiler boyutlarına ilişkin görüşlerine daha fazla katılım göstermişlerdir. Liselerde çalışan öğretmenler, ilkokullarda ve ortaokullarda çalışan öğretmenlere göre istismarcı yönetime ilişkin ifadelere daha çok katılmışlardır. Son olarak katılımcıların istismarcı yönetime ilişkin görüşleri ile öç alma nedenlerine ve davranışsal tepkilere ilişkin görüşleri arasında düşük düzeyde pozitif ve anlamlı ilişki olduğu belirlenmiştir.

Anahtar Sözcükler: İstismarcı Yönetim, Öç Alma, Eğitim Örgütleri, Öğretmen Görüşleri

\section{The Relationship Between Abusive Management and Organizational Revenge Behavior in Educational Organizations}

\begin{abstract}
The aim of this research was to determine the correlation between abusive management and revenge behavior in educational organizations. The Abusive Management scale and the Organizational Revenge scale were applied to 361 teachers working in public schools in Ankara. The findings showed that male teachers were more likely to agree with the statements related to abusive management and the behavioral reactions factor of the organizational revenge scale. There was a significant difference between the views on the reasons for taking revenge and the behavioral reactions according to the educational status variable. Teachers who had experience between 0-10 years and 11-20 years differed significantly in terms of their views about abusive management. Teachers working in high schools were more likely to agree with the statements related to abusive management than teachers working in the secondary schools. Finally, there was a low positive and significant relationship between the views of the participants about the abusive management and their views on the reasons for taking revenge and behavioral reactions.
\end{abstract}

Keywords: Abusive Management, Revenge, Educational Organizations, Teachers' View 
Türkiye'de eğitim, özel girişime de açı bir kamu hizmeti olarak devletin önem verdiği ve yönetici, öğretmen, müfettiş, uzman, öğrenci, veli gibi unsurları içeren bir alandır. Bu unsurlar arasındaki ilişkiler, ortaya çıkan yeni yönetim anlayışları ve yönetim teknikleri ile şekillendikçe önem kazanmaya başlamıştır. Bu ilişkilerin doğru anlaşılması, özellikle yöneticiler ve öğretmenler arasında var olan sorunların tespit edilmesine ve bu sorunları gidermeye yönelik uygun çözüm yolunun bulunmasına katkı sağlar. Aksi takdirde yönetici ve öğretmenler arasındaki ilişki gerginleşir. Eğitim örgütünün işleyişi ve performansı kaçınılmaz olarak bu gerginlikten olumsuz etkilenir (Başaran ve Çınkır, 2013; Üçok ve Turgut, 2014).

Örgüt üzerine yapılan araştırmalara bakıldığında, yönetici ve çalışan arasındaki ilişkinin olumsuz olduğu durumlarla ilgili yapılan araştırmalardan bazılarının istismarcı yönetim kavramı hakkında olduğu görülür (Martinko, Harvey, Brees ve Mackey, 2013). İstismarcı yönetim, “ast konumundaki çalışanların yöneticisinin sürekli biçimde yaptığı, fiziksel teması içermeyen, sözel veya sözel olmayan düşmanca davranışlarına ilişkin algılarıdır" (Tepper, 2000, s. 178). Tepper (2000)'in bu tanımı, istismarcı yönetimi kişisel bir değerlendirme olarak betimler. Aynı kişi yöneticinin bazı konulardaki davranışını, istismarcı olarak değerlendirirken, başka bazı konulardaki davranışını istismarcı olarak görmeyebilir. Hatta aynı yöneticinin davranışını iki çalışan farklı değerlendirebilir (Tepper, 2000).

İstismarcı yönetim hem ahlaki standartları ihlal etmesi sebebiyle, etik dışı davranış olarak algılandığı, hem de istismarcı yönetimin hedefindekilerin etik açıdan tartışmaya açık davranışlarına karşılık yaptırım niteliğinde uygulandığı için iş ortamının etik yönden zarar görmesine yol açmaktadır (Park ve ark., 2017). Tepper (2000)'e göre, istismarcı yönetime maruz kalan ast konumundaki çalışan olumsuz tepki vermektedir; çünkü istismarcı yönetim işlerin nasıl olması gerektiği yönündeki çalışan algılarından oluşan normatif adalet kurallarını ihlal etmektedir.

İstismarcı yönetime örnek olarak çalışanın herkesin önünde eleştirilmesi, yöneticinin yüksek sesle ve sinirli biçimde bağırıp çağırması, yöneticinin kabalığı, düşüncesiz bencil davranışları, yöneticinin çalışan üzerinde baskı uygulaması gibi davranışlar sayılabilir (Bies 2001; Bies ve Tripp, 1998; Tepper, 2000). Çalışanların böyle davranışlara maruz kalması durumunda tükenmişlik, adaletsizlik algısı, performansın düşmesi, işe devam etmeme, işten ayrılma ve işten tatmin olmama gibi etkilerin oluşabileceği alanyazınında belirtilmektedir (Aryee, Chen, Sun ve Debrah, 2007; Harvey, Stoner, Hochwarter ve Kacmar, 2007; Neuman ve Baron, 1996; Tepper, 2000; Ülbeği, Mimaroğlu Özgen ve Özgen, 2014; Zellars, Tepper ve Duffy, 2002). Bu tür durumlarda, ast konumundaki çalışanın istismarcı yöneticisine karşı aynı şekilde davranarak öç alması söz konusu olabilir (Tepper, 2000).

Pek çok araştırmacının vurguladığı gibi yöneticiler astları üzerinde güç sahibidirler; bunun sonucu olarak istismarcı yönetici, astın alabileceği ödülü ona vermemek, cezalandırmak ya da karşı öç alma davranışına girişmek gibi eylemlerde bulunabilir (Aquino, Tripp, ve Bies, 2006; Tepper ve ark. 2009). Öte yandan araştırmalar, istismarcı yönetim ile yöneticiye yönelen öç alma davranışının ilişkisi olduğunu da göstermektedir (Inness, Barling, ve Turner, 2005; Liu, Kwan, Wu ve Wu, 2010; Tepper ve ark., 2009). Berkowitz (1989)'un ifade ettiği gibi ast konumundaki çalışanlar, yöneticileri tarafından kışkırtıldıkları takdirde düşmanca davranışlarda bulunabilir ve benzer davranışlarda bulunma eğilimi gösterebilirler. Sinirlendirilmiş, kışkırtılmış bireylerin, kendilerini kışkırtanlardan öç almak ve onları cezalandırmak için, onlara karşı mantık dışı davrandıkları ve davranışlarının uzun dönem sonuçlarını göz ardı ettikleri bilinir (de Quervain ve ark., 2004; Leith ve Baumeister, 1996; Lian ve ark. 2014). Öç alma, bireyin bir hareketi yanlış bir davranış olarak algılaması ve bu davranışa karşılık olarak ona acı çektirmesi şeklinde tanımlanmaktadır (Nayir, 2016; Stuckless ve Goranson, 1992). Alanyazında öç almanın planlı bir davranış olduğu vurgulanmakta ve genellikle zarar verici bir harekete karşıllk olarak yapıldığı ifade edilmektedir (Bies ve Tripp, 2005; Fromm, 1973; Nayir, 2015). Kısacası öç alma, bireyin haksızlığa veya kötü bir davranışa maruz kaldığında, karşısındakine planlı biçimde zarar vermeye çalışmasıdır. Öç alma, bireyleri olumsuz etkileyen bir duygudur. Robinson ve Bennett (1995) öç almanın sadece kişi için değil örgüt için de kötü olduğunu belirtmekteler ve öç alma davranışını olumsuz iş yeri davranışları arasında saymaktadırlar. Çünkü bu davranışlar örgütün hedeflerine ulaşması olasılığını olumsuz etkilemekte ve çalışanların gündelik hayat akışı ve iş yaşamları ise bu davranışlardan istenmeyen biçimde etkilenmektedir (Mount, Ilies ve Johnson, 2006). 
Türkiye'deki çalışmalara bakıldığında Üçok ve Turgut'un (2014) da benzer şekilde ifade ettiği üzere, istismarcı yönetici davranışlarının bilimsel olarak henüz yeni yeni incelenmeye başlandığı, ancak bu tür davranışların eğitim örgütlerinde ne düzeyde gözlendiğine dair sağlam bilginin oluşmadığı söylenebilir. İstismarcı yönetici davranışlarının eğitim örgütlerinde hangi düzeyde görüldüğü ve bu davranışların olumsuz sonuçlarına dair bilgi edinilmesinin, eğitim örgütlerinin yönetiminde bu davranışların yıkıcı sonuçlarının önlenmesine katkı sağlayacağı düşünülmektedir. Öte yandan ulusal alanyazında, öç alma davranışı ile ilgili araştırmaların yetersiz olduğu görülmektedir. Öç alma davranışının Türkiye'de akademik örgütlerde (Şener ve Erdem, 2014), özel şirketlerde (Tatarlar ve Güneri- Çangarlı, 2014) ve eğitim örgütlerinde (Nayir, 2015; 2016) araştırıldığı görülmektedir. Eğitim örgütlerinde yapılan çalışmanın öç almanın neden ve sonuçlarına ilişkin olduğu anlaşılmaktadır (Nayir, 2016). Ancak eğitim örgütlerinde karşılaşılan öç alma davranışlarının olumsuz sonuçlarının ortadan kaldırılması için yöneticilerin ne tür yaklaşımlarda bulunması gerektiğine ilişkin bir çalışmaya rastlanmamıştır. Bu sebeple yöneticilerin, yönetim tarzları ile öç alma davranışları arasında ilişki olup olmadığını irdeleyen çalışmalara ihtiyaç olduğu açıktır. Bu yüzden alanyazındaki bu boşluğu doldurmak amacıyla bu çalışmada eğitim örgütlerinde istismarcı yönetim ve örgütsel öç alma arasındaki ilişki açılanmaya çalışılmaktadır.

Bu doğrultuda, bu araştırmanın amacı eğitim örgütlerinde istismarcı yönetim ve öç alma davranışı arasındaki ilişkiyi belirlemektir. Bu amaç doğrultusunda aşağıdaki sorulara cevap aranmıştır:

1. Öğretmenlerin istismarcı yönetime ilişkin görüşleri nasıldır?

2. Öğretmenlerin öç alma davranışına ilişkin görüşleri nasıldır?

3. Öğretmenlerin istismarcı yönetime ilişkin görüşleri cinsiyete, kıdeme, branşa ve okul türüne göre istatistiksel olarak anlamlı farklılık göstermekte midir?

4. Öğretmenlerin öç alma davranışına ilişkin görüşleri cinsiyete, kıdeme, branşa ve okul türüne göre istatistiksel olarak anlamlı farklılık göstermekte midir?

5. Öğretmenlerin istismarcı yönetim ile öç alma davranışları arasında istatistiksel olarak anlamlı bir ilişki var midir?

\section{Yöntem}

Eğitim örgütlerinde istismarcı yönetim ve öç alma davranışı arasındaki ilişkiyi belirlemeyi amaçlayan bu çalışmada ilişkisel tarama modeli kullanılmıştır. İlişkisel (korelatif) araştırmalar, iki ya da çok sayıda değişken arasında ilişki bulunup bulunmadığını saptamaya yönelik araştırma desenleridir (Fraenkel ve Wallen, 2006).

\section{Evren ve Örneklem}

Araştırmanın evrenini Ankara' daki kamu okullarında görev yapmakta olan öğretmenler oluşturmaktadır. Bu doğrultuda araştırmanın verileri 2017-2018 eğitim öğretim yılında Ankara il merkezinde kamu okullarında görevli öğretmenlerden elde edilmiştir. Evrenin araştırmacının ulaşamayacağı boyutta olması nedeniyle örneklem alma yoluna gidilmiştir. Ankara İl Milli Eğitim Müdürlügü̈nün istatistiklerine göre 2017-2018 eğitim öğretim yılında Ankara' da kamu okullarında toplam 69.257 öğretmen görev yapmaktadır. Anderson'a göre (1990), 381 kişilik bir örneklem büyüklüğü 50.000 kişilik bir evrenin \%5 tolerans gösterilebilir hata pay1 ile temsil edilebilmesini sağlar. Buna göre 381 öğretmene ulaşılması yeterlidir. Bu nedenle ölçekler Ankara il merkezinde kamu okullarında çalışmakta olan ve basit tesadüfi örnekleme yöntemine göre seçilen 650 öğretmene dağıtılmış geri dönen 529 ölçekten, eksik doldurulmuş anketlerin (\%5'ten fazla kayıp verisi bulunan) ve uç değerlerin çıkartılmasıyla 361 veri analize alınmıştır. Araştırmaya katılan katılımcıların kişisel bilgilerine ait frekans ve yüzde dağılımları Tablo I'de sunulmuştur. 
Tablo I

Katılımcıların Kişisel Bilgilerine Ait Frekans ve Yüzde Dağılımları

\begin{tabular}{|c|c|c|c|c|}
\hline Değişkenler & Grup & $\mathbf{N}$ & $\%$ & Toplam \\
\hline \multirow{3}{*}{ Cinsiyet } & Kadın & 266 & 73,7 & \multirow{3}{*}{361} \\
\hline & Erkek & 93 & 25,8 & \\
\hline & Kayıp Değer & 2 & 0,6 & \\
\hline \multirow{3}{*}{ Kıdem } & 0-10 yıl arası & 88 & 24,4 & \multirow{3}{*}{361} \\
\hline & $11-20$ yıl arası & 138 & 38,2 & \\
\hline & 21 yıl ve üzeri & 126 & 34,9 & \\
\hline \multirow{4}{*}{ Okul Türü } & İlkokul & 65 & 18,0 & \multirow{4}{*}{361} \\
\hline & Ortaokul & 82 & 22,7 & \\
\hline & Lise & 210 & 58,2 & \\
\hline & Kayıp Değer & 4 & 1,1 & \\
\hline \multirow{5}{*}{ Eğitim Düzeyi } & Önlisans & 5 & 1,4 & \multirow{5}{*}{361} \\
\hline & Lisans & 308 & 85,3 & \\
\hline & Yüksek Lisans & 44 & 12,2 & \\
\hline & Doktora & 2 & 0,6 & \\
\hline & Kayıp Değer & 2 & 0,6 & \\
\hline \multirow{7}{*}{ Branş } & Sınıf öğretmeni & 57 & 15,8 & \multirow{7}{*}{361} \\
\hline & Yabanci dil & 49 & 13,6 & \\
\hline & Türkçe & 38 & 10,5 & \\
\hline & Fen-Matematik & 89 & 24,7 & \\
\hline & Sözel & 39 & 10,8 & \\
\hline & Diğer & 82 & 22,7 & \\
\hline & Kayıp Değer & 7 & 1,9 & \\
\hline
\end{tabular}

Tablo I'de görüldüğü gibi katılımcıların \% 73,7 si kadın, \%25,8'i erkektir. Katılımcıların çoğunluğu lisans mezunu (\% 85,3) ve 11 - 20 yıl arası kıdeme sahiptir (\%38,2). Katılımciların \% 18'i ilkokulda, \% 22,7'si ortaokulda, \% 58,2'si lisede görev yapmaktadır. Katılımcıların çoğunluğu fen-matematik branşında (\%22,7) görev yapmaktadır.

\section{Veri Toplama Araçları}

Araştırmada Tepper (2000) tarafından geliştirilen ve Ülbeği, Mimaroğlu Özgen ve Özgen (2014) tarafından Türkçeye uyarlanan İstismarcı Yönetim ölçeği ve Nayir (2016) tarafından geliştirilen Örgütsel Öç Alma Ölçeği hem ilgili araştırmacılardan hem de Milli Eğitim Bakanlığı'ndan izin alınarak uygulanmıştır. Beşli likert olarak (hiç katılmıyorum, az katılıyorum, orta derecede katılıyorum, çok katılıyorum, tamamen katılıyorum) hazırlanmış ölçek, İstismarcı Yönetim Ölçeği 15 maddeden oluşmaktadır ve ölçek tek boyutludur. Ülbeği, Mimaroğlu Özgen ve Özgen (2014) tarafından istismarcı yönetim ölçeğinin yapı geçerliğini belirlemek üzere yapılan faktör analizi yapılmış ve varyansın \%72'sini açıklayan tek faktörlü bir yapı ortaya çıkarılmıştır. Örgütsel Öç Alma ölçeği de beşli likert olarak hazırlamış, 25 maddeden oluşmakta ve ölçeğin "öç alma nedenleri", "duygusal tepkiler", "davranışsal tepkiler" olmak üzere üç alt boyutu bulunmaktadır. Nayir (2016) geliştirdiği örgütsel öç alma ölçeği için güvenirlik analizi yapmış ve "öç alma nedenleri" faktörü için .94, "davranışsal tepkiler" faktörü için .89 ve "duygusal tepkiler" faktörü için .67 olduğunu belirtmiştir. Örgütsel öç alma ölçeğinin toplamında alfa katsayısı .88 olduğu ortaya çıkmıştır.

\section{Veri Toplama Araçlarına İlişkin Doğrulayıcı Faktör Analizi Sonuçları}

Bu çalışmada ölçekler için Doğrulayıcı Faktör Analizi (DFA) yapılmıştır. DFA analizleri 361 kişiden oluşan veri seti üzerinden tesadüfi olarak çekilen 261 veri üzerinden yapılmıştır. İstismarcı yönetim ölçeği için yapılan ilk DFA analizi sonucunda uyum indekslerinin $\chi^{2}=565.65, p=0.000, s d=90, \chi 2 / s d=6.28$, $\mathrm{CFI}=0,91, \mathrm{NFI}=.89, \mathrm{NNFI}=.89, \mathrm{GFI}=.83, \mathrm{AGFI}=.77, \mathrm{IFI}=.91, \mathrm{RFI}=.87$ ve $\mathrm{RMSEA}=.121$ olduğu görülmüştür. Analiz ile ilgili modifikasyon önerileri incelendiğinde 1-2, 1-4, ve 8-14 maddeler arasında modifikasyon yapılmasının uygun olduğu görülmüş bunun üzerine ilgili madde çiftleri arasında modifikasyon yapılarak analiz tekrar edilmiştir. Buna göre uyum indeksleri $\chi 2=286.07, \mathrm{p}=0.0000, \mathrm{sd}=86, \chi 2 / \mathrm{sd}=3.32, \mathrm{CFI}=0,94$, $\mathrm{NFI}=.92, \mathrm{NNFI}=.93, \mathrm{GFI}=.87, \mathrm{AGFI}=.82, \mathrm{IFI}=.94, \mathrm{RFI}=.90$ ve $\mathrm{RMSEA}=.095$ olarak hesaplanmıştır. 
Örgütsel öç alma ölçeğine ilişkin yapılan DFA sonucunda uyum indekslerinin $\quad \chi 2=798.64, p=0.000$, $\mathrm{sd}=272, \chi 2 / \mathrm{sd}=2.93, \mathrm{CFI}=0,96, \mathrm{NFI}=.93, \mathrm{NNFI}=.95, \mathrm{GFI}=.80, \mathrm{AGFI}=.76, \mathrm{IFI}=.96, \mathrm{RFI}=.93$ ve RMSEA $=.086$ olduğu görülmüştür. Bütün bulgular bir arada incelendiğinde örneklem grubunun büyüklüğüne bağlı olarak ölçme aracına ilişkin yapının doğrulandığını, ölçeklerin yapısal ve istatistiksel olarak uygun bir ölçek olduğunu söylemek mümkündür.

Ölçekler için güvenirlik katsayıları da hesaplanmıştır. Cronbach Alfa katsayısı istismarcı yönetim için .87, örgütsel öç alma ölçeği için faktörlerin sırasına göre $.94, .86, .86$ ve ölçeğin bütününe ilişkin .87 olarak hesaplanmıştır.

\section{Verilerin Analizi}

Verilerin analizinde SPSS 24 paket programı kullanılmıştır. Verilerin analizine başlamadan önce dağılımın normalliği test edilmiştir. Bunun için öncelikle aritmetik ortalama, medyan ve mod değerlerine bakılmış birbirine yakın olduğu görülmüştür. Ayrıca basıklık ve çarpıklık katsayıları, Q-Q plot grafikleri incelenmiş ve dağılımın normale yakın olduğu görülmüştür. Bu değerlendirmeler sonucunda dağılımın normal olduğu varsayılarak verilerin analizinde parametrik testlerin kullanılmasına karar verilmiştir.

Verilerin analizi betimsel istatistiklerle birlikte DFA, bağımsız örneklem t-testi, ANOVA ve Pearson korelasyon ile çözümlenmiştir. Verilerin analizinde eğitim durumu ve cinsiyet değişkenleri için t-testi yapılmıştır. Branş, kıdem ve okul türü değişkenleri için ANOVA yapılmıştır. İstismarcı yönetim ile öç alma davranışı arasındaki ilişkiyi ortaya çıkarmak için korelasyon analizi kullanılmıştır. ANOVA testi sonucuna göre, anlamlı fark tespit edilen gruplerda farkın kaynağını belirlemek amacıyla varyansların homojenliğine bakılmıştır. Varyansların homojen olması durumunda Scheffe testi, heterojen olması durumundaysa Dunnet $\mathrm{C}$ testinden yararlanılmıştır. Manidarlık sınamalarında anlamlılık düzeyi .05 alınmıştır. Verilerin analizinde eğitim durumu değişkeninde önlisans lisans kategorisiyle birleştirilerek lisans adı altında, doktora ve yüksek lisans grubu birleştirilerek lisansüstü adı altında kategorilendirilmiştir. Kıdem değişkeni, veriler toplanırken sürekli değişken olarak alınmış, sürekli değişken ile fark analizleri yapılmadığı için analiz sürecinde kategorilendirilmiştir.

\section{Bulgular}

Öğretmenlerin istismarcı yönetime ilişkin görüşlerini gösteren betimsel istatistikler Tablo II'de gösterilmiştir.

\section{Tablo II}

İstismarcı Yönetime İlişkin Öğretmen Görüşlerinin Aritmetik Ortalaması, Standart Sapması ve Puan Sırası

\begin{tabular}{clccc}
\hline & \multicolumn{1}{c}{ Maddeler } & X & ss & Puan Sirası \\
\hline 1 & Yöneticim benimle alay eder. & 1,06 &, 33 & 10,5 \\
\hline 2 & Yöneticim duygu ve düşüncelerimi aptalca bulur. & 1,05 &, 27 & 12,5 \\
\hline 3 & Yöneticim bana küser. & 1,20 &, 51 & 3 \\
\hline 4 & Yöneticim beni başkalarının önünde aşağılar. & 1,07 &, 29 & 9 \\
\hline 5 & Yöneticim özel hayatımı ihlal eder. & 1,06 &, 28 & 10,5 \\
\hline 6 & Yöneticim geçmişteki hatalarımı yüzüme vurur. & 1,15 &, 44 & 6 \\
\hline 7 & Yöneticim işteki çabalarımı takdir etmez. & 1,42 &, 76 & 1 \\
\hline 8 & Yöneticim beni kendini utandırmakla suçlar. & 1,03 &, 21 & 14 \\
\hline 9 & Yöneticim sözünde durmaz. & 1,22 &, 53 & 2 \\
\hline 10 & Yöneticim başkasına olan hıncını benden çlkartır. & 1,19 &, 49 & 4 \\
\hline 11 & Yöneticim benim hakkımda başkalarına olumsuz yorumlarda bulunur. & 1,18 &, 50 & 5 \\
\hline 12 & Yöneticim bana karşı kabadır. & 1,14 &, 44 & 7 \\
\hline 13 & Yöneticim iş arkadaşlarımla etkileşim halinde olmama izin vermez. & 1,05 &, 28 & 12,5 \\
\hline 14 & Yöneticim beceriksiz olduğumu söyler. & 1,02 &, 15 & 15 \\
\hline 15 & Yöneticim bana yalan söyler. & 1,11 &, 39 & 8 \\
\hline
\end{tabular}

Tablo II incelendiğinde, öğretmenlerin en çok "Yöneticim işteki çabalarımı takdir etmez." $(1,42)$, "Yöneticim sözünde durmaz." $(1,22)$ ve "Yöneticim bana küser." $(1,20)$ maddelerine katılırken; en az "Yöneticim beceriksiz olduğumu söyler." (1,02), "Yöneticim beni kendini utandırmakla suçlar." $(1,03)$, 
"Yöneticim duygu ve düşüncelerimi aptalca bulur." $(1,05)$ ve "Yöneticim iş arkadaşlarımla etkileşim halinde olmama izin vermez." $(1,05)$ maddelerine katıldıkları görülmektedir.

\section{Öğretmenlerin Öç Alma Davranışına İlișkin Görüşleri}

Öğretmenlerin öç alma davranışına ilişkin görüşlerini gösteren betimsel istatistikler Tablo III'te gösterilmiştir.

\section{Tablo III}

Öç Alma Davranışına İlişkin Öğretmen Görüşlerinin Aritmetik Ortalaması, Standart Sapması ve Puan Strası

\begin{tabular}{|c|c|c|c|c|c|}
\hline & No & Maddeler & $\mathrm{X}$ & ss & $\begin{array}{l}\text { Puan } \\
\text { Sirasi }\end{array}$ \\
\hline \multirow{11}{*}{ 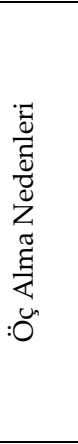 } & 1. & Bana karşı adaletsiz bir uygulama yapıldığında öç almak istiyorum. & 1,43 & ,73 & 6,5 \\
\hline & 2 & Değer görmediğimde öç almak istiyorum. & 1,31 & ,66 & 11 \\
\hline & 3. & Herhangi bir sebepten ayrımcılık yapıldığında öç almak istiyorum. & 1,44 & ,76 & 5 \\
\hline & 4. & İhtiyacım olan durumlarda izin verilmediğinde öç almak istiyorum. & 1,33 & 66 & 10 \\
\hline & 5. & Hakkımda dedikodu yapıldığında öç almak istiyorum. & 1,41 & ,76 & 8 \\
\hline & 6. & Bana saygısız davranıldığında öç almak istiyorum. & 1,51 & ,88 & 3 \\
\hline & 7. & Bana hakaret edildiğinde öç almak istiyorum. & 1,64 & 1,01 & 2 \\
\hline & 8. & Cinsiyetçi ifadeler kullanıldığında öç almak istiyorum. & 1,47 & ,81 & 4 \\
\hline & 9. & Herhangi bir sebepten dolayı dışlandığımda öç almak istiyorum. & 1,34 & 68 & 9 \\
\hline & 10. & Ortak alınması gereken kararlarda sürece dâhil edilmediğimde öç almak istiyorum. & 1,43 & 75 & 6,5 \\
\hline & 11. & Özlük haklarım keyfi olarak engellendiğinde/kullandırılmadığında öç almak istiyorum. & 1,77 & 1,12 & 1 \\
\hline \multirow{5}{*}{ 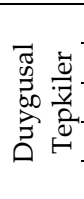 } & 12 & Öç alma duygusu hissettiğimde bu duyguyu bastırmaya çalışıyorum. & 2,90 & 1,56 & 3 \\
\hline & 13. & Öç alma duygusu hissettiğimde olayı unutmaya çalışıyorum. & 2,91 & 1,49 & 2 \\
\hline & 14. & Bana öç almayı hissettiren kişinin açı̆̆ını arıyorum. & 2,86 & 1,38 & 4 \\
\hline & 15. & Öç alma duygusundan utaniyorum. & 2,65 & 1,48 & 5 \\
\hline & 16. & Öç almanın ilkel bir davranış olduğunu düşünüyorum. & 3,20 & 1,59 & 1 \\
\hline \multirow{9}{*}{ 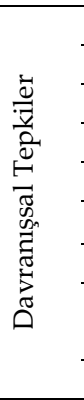 } & 17. & Öç alma duygusu hissettiğimde okuldaki herkesten nefret ediyorum. & 1,31 & 67 & 2 \\
\hline & 18. & Öç almak istediğimde buna neden olan kişiyi bir üst kuruma şikâyet ediyorum. & 1,35 & 69 & 1 \\
\hline & 19. & Öç almak istediğimde okulda çatışma ortamı yaratıyorum. & 1,11 & ,39 & 8 \\
\hline & 20. & Öç almak istediğimde görevimi aksatıyorum. & 1,14 & 40 & 6 \\
\hline & 21. & Öç alma duygusu hissettiğimde okulda çözebileceğim sorunları çözmüyorum. & 1,24 & 60 & 4,5 \\
\hline & 22. & Öç alma duygusu hissettiğimde buna neden olan kişiyle ilgili dedikodu yapıyorum. & 1,24 & ,53 & 4,5 \\
\hline & 23. & Öç alma duygusu hissettiğimde Buna neden olan kişiye zarar vermek istiyorum. & 1,13 & ,41 & 7 \\
\hline & 24. & $\begin{array}{l}\text { Öç alma duygusu hissettiğimde bana bunu hissettiren kişinin dışlanmasına yol açacak } \\
\text { ortamlar hazırlıyorum. }\end{array}$ & 1,10 & ,38 & 9 \\
\hline & 25. & Öç alma duygusu hissettiğimde okulda sürekli her şeyi eleştiriyorum. & 1,25 & ,56 & 3 \\
\hline
\end{tabular}

Tablo III'e bakıldığında "Öç Alma Nedenleri” boyutunda öğretmenlerin en çok, "Özlük haklarım keyfi olarak engellendiğinde/kullandırılmadığında öç almak istiyorum." (1,77); "Bana hakaret edildiğinde öç almak istiyorum." (1,64) ve "Bana saygısız davranıldığında öç almak istiyorum." $(1,51)$ ifadelerine katıldıkları görülmektedir. Öğretmenlerin "Öç Alma Nedenleri" boyutunda en az katıldıkları ifadelerin, "Değer görmediğimde öç almak istiyorum." $(1,31)$, "İhtiyacım olan durumlarda izin verilmediğinde öç almak istiyorum." $(1,33)$ ve "Herhangi bir sebepten dolayı dışlandığımda öç almak istiyorum." $(1,34)$ ifadelerinin olduğu Tablo III'ten anlaşılmaktadır. "Duygusal Tepkiler" boyutunda öğretmenlerin en çok "Öç almanın ilkel bir davranış olduğunu düşünüyorum." (3,20), ifadesine katılırken, en az "Öç alma duygusundan utanıyorum." (2,65) ifadesine katıldıkları görülmektedir. Son olarak "Davranışsal Tepkiler" boyutunda öğretmenlerin en çok "Öç almak istediğimde buna neden olan kişiyi bir üst kuruma şikâyet ediyorum." (1,35), "Öç alma duygusu hissettiğimde okuldaki herkesten nefret ediyorum." $(1,31)$ ve "Öç alma duygusu hissettiğimde okulda sürekli her şeyi eleştiriyorum." $(1,25)$ ifadelerine katılırken, en az "Öç alma duygusu hissettiğimde bana bunu hissettiren kişinin dışlanmasına yol açacak ortamlar hazırlıyorum." $(1,10)$, "Öç almak istediğimde okulda çatışma ortamı yaratıyorum." (1,11) ifadelerine katıldıkları görülmektedir.

\section{Cinsiyet Değişkenine Göre Öğretmenlerin İstismarcı Yönetim ve Öç Almaya İlişkin Görüşleri}

Katılımcıların istismarcı yönetim ve öç alma davranışına ilişkin görüşlerinin cinsiyete göre farklılaşıp farklılaşmadığ $1 \mathrm{t}$ testi ile incelenmiş ve sonuçlar Tablo IV'te sunulmuştur. 
Tablo IV

Cinsiyet Değişkenine Göre T-Testi Sonuçları

\begin{tabular}{|c|c|c|c|c|c|c|c|}
\hline & Kategoriler & $\mathbf{N}$ & $\bar{X}$ & ss & sd & $t$ & p \\
\hline \multirow{2}{*}{ İstismarcı Yönetim } & Kadın & 266 & 16,7406 & 3,35627 & \multirow{2}{*}{357} & \multirow{2}{*}{2,07} & \multirow{2}{*}{.040} \\
\hline & Erkek & 93 & 17,8280 & 4,64061 & & & \\
\hline \multirow{2}{*}{ 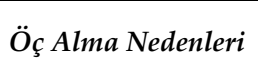 } & Kadın & 265 & 15,7132 & 7,08557 & \multirow[t]{2}{*}{356} & \multirow{2}{*}{1,49} & \multirow{2}{*}{.136} \\
\hline & Erkek & 93 & 17,0000 & 7,29204 & & & \\
\hline \multirow{2}{*}{ Duygusal Tepkiler } & Kadın & 266 & 14,3571 & 6,04233 & \multirow[t]{2}{*}{357} & \multirow{2}{*}{1,24} & \multirow{2}{*}{.214} \\
\hline & Erkek & 93 & 15,2581 & 5,92875 & & & \\
\hline \multirow{2}{*}{$\begin{array}{l}\text { Davranışsal } \\
\text { Tepkiler }\end{array}$} & Kadın & 266 & 10,3835 & 2,50651 & \multirow[t]{2}{*}{357} & \multirow{2}{*}{3,91} & \multirow{2}{*}{.000} \\
\hline & Erkek & 93 & 12,3441 & 4,59322 & & & \\
\hline
\end{tabular}

Tablo IV incelendiğinde katılımcıların görüşleri arasında cinsiyet değişkenine göre öç alma nedenleri $\left[\mathrm{t}_{(356)}=1,49 ; \mathrm{p}>.05\right]$ ve duygusal tepkiler $\left[\mathrm{t}_{(357)}=1,24 ; \mathrm{p}>.05\right]$ boyutlarında istatistiksel olarak anlamlı fark bulunmamaktadır. Cinsiyet değişkenine göre istismarcı yönetime $[t(357)=2,07 ; p<.05]$ ve örgütsel öç almanın davranışsal tepkiler $\left[\mathrm{t}_{(357)}=3,91 ; \mathrm{p}>.05\right]$ boyutuna ilişkin görüşler arasında ise anlamlı fark vardır. Her iki boyutta erkek öğretmenler istismarcı yönetime ilişkin ifadelere kadın öğretmenlere göre daha fazla katılmaktadırlar.

\section{Eğitim Durumu Değişkenine Göre Öğretmenlerin İstismarcı Yönetim ve Öç Almaya İlişkin Görüşleri}

Katılımcıların istismarcı yönetim ve öç alma davranışına ilişkin görüşlerinin eğitim durumuna göre farklılaşıp farklılaşmadığı $\mathrm{t}$ testi ile incelenmiş ve sonuçlar Tablo $V^{\prime}$ te gösterilmiştir.

Tablo V

Ĕ̆itim Durumu Değişkenine Göre T-Testi Sonuçları

\begin{tabular}{|c|c|c|c|c|c|c|c|}
\hline & Kategoriler & $\mathbf{N}$ & $\bar{X}$ & ss & sd & $\mathbf{t}$ & p \\
\hline \multirow{2}{*}{ İstismarcı Yönetim } & Lisans & 313 & 16,9137 & 3,71530 & \multirow{2}{*}{357} & \multirow{2}{*}{1,72} & \multirow{2}{*}{.086} \\
\hline & Lisansüstü & 46 & 17,9348 & 4,02990 & & & \\
\hline \multirow{2}{*}{ Öç Alma Nedenleri } & Lisans & 312 & 15,6090 & 6,79282 & \multirow{2}{*}{356} & \multirow{2}{*}{2,56} & \multirow{2}{*}{.013} \\
\hline & Lisansüstü & 46 & 19,0870 & 8,81117 & & & \\
\hline \multirow{2}{*}{ Duygusal Tepkiler } & Lisans & 313 & 14,5144 & 6,09544 & \multirow{2}{*}{357} & \multirow{2}{*}{, 51} & \multirow{2}{*}{.610} \\
\hline & Lisansüstü & 46 & 15,0000 & 5,50555 & & & \\
\hline \multirow{2}{*}{ Davranışsal Tepkiler } & Lisans & 313 & 10,7604 & 3,21407 & \multirow{2}{*}{357} & \multirow{2}{*}{2,14} & \multirow{2}{*}{.033} \\
\hline & Lisansüstü & 46 & 11,8696 & 3,69750 & & & \\
\hline
\end{tabular}

Tablo V incelendiğinde katılımcıların görüşleri arasında eğitim durumu değişkenine göre istismarcı yönetim [ $\left[\mathrm{t}_{(357)}=1,72 ; \mathrm{p}>.05\right]$ ve duygusal tepkiler $\left[\mathrm{t}_{(357)}=, 51 ; \mathrm{p}>.05\right]$ boyutlarında anlamlı bir fark yoktur. Eğitim durumu değişkenine göre öç alma nedenlerine $\left[t_{(356)}=2,56 ; p<.05\right]$ ve davranışsal tepkiler $[t(357)=2,14 ; p<.05]$ boyutlarına ilişkin görüşler arasında ise anlamlı bir fark vardır. Her iki boyutta da lisansüstü mezunu öğretmenler lisans mezunu öğretmenlere göre bu boyutlardaki ifadelere daha fazla katılmaktadırlar.

\section{Kıdem Değişkenine Göre Öğretmenlerin İstismarcı Yönetim ve Öç Almaya İlişkin Görüşleri}

Katılımcıların istismarcı yönetim ve öç alma davranışına ilişkin görüşlerinin kıdem değişkenine göre farklılaşıp farklılaşmadığı ANOVA testi ile incelenmiş, farkın kaynağı ise Dunnet $C$ testi ile tespit edilmiş ve sonuçlara TabloVI'te yer verilmiştir.

Tablo VI

Kıdem Değişkenine Göre ANOVA Testi Sonuçları

\begin{tabular}{|c|c|c|c|c|c|c|c|c|}
\hline & Kategoriler & $\mathbf{N}$ & $\bar{X}$ & Ss & Sd & F & $\mathrm{p}$ & $\begin{array}{c}\text { Anlamlı Fark } \\
\text { (Dunnet C) }\end{array}$ \\
\hline \multirow{3}{*}{$\begin{array}{l}\text { İstismarcı } \\
\text { Yönetim }\end{array}$} & $0-10$ y1l arası & 88 & 17,39 & 3,92 & \multirow{3}{*}{2,349} & \multirow{3}{*}{4,65} & \multirow{3}{*}{.011} & \multirow{3}{*}{$\begin{array}{l}1-2 \\
2-3\end{array}$} \\
\hline & $11-20$ yıl arası & 138 & 16,27 & 2,35 & & & & \\
\hline & 21 ve üzeri & 126 & 17,51 & 4,45 & & & & \\
\hline \multirow{3}{*}{$\begin{array}{l}\text { Öç Alma } \\
\text { Nedenleri }\end{array}$} & $0-10$ yıl arası & 87 & 16,98 & 9,04 & \multirow{3}{*}{2,348} & \multirow{3}{*}{2,77} & \multirow{3}{*}{.064} & \\
\hline & $11-20$ yil arası & 138 & 16,43 & 6,73 & & & & \\
\hline & 21 ve üzeri & 126 & 14,84 & 5,79 & & & & \\
\hline
\end{tabular}




\begin{tabular}{|c|c|c|c|c|c|c|c|}
\hline \multirow{3}{*}{$\begin{array}{l}\text { Duygusal } \\
\text { Tepkiler }\end{array}$} & $0-10$ yıl arası & 88 & 15,07 & 5,46 & \multirow{3}{*}{2,349} & \multirow{3}{*}{1,49} & \multirow{3}{*}{.225} \\
\hline & $11-20$ y1l arası & 138 & 14,78 & 5,72 & & & \\
\hline & 21 ve üzeri & 126 & 13,77 & 6,54 & & & \\
\hline \multirow{3}{*}{$\begin{array}{l}\text { Davranışsal } \\
\text { Tepkiler }\end{array}$} & $0-10$ yıl arası & 88 & 10,73 & 2,78 & \multirow{3}{*}{2,349} & \multirow{3}{*}{ 146 } & \multirow{3}{*}{.864} \\
\hline & $11-20$ y1l aras1 & 138 & 10,84 & 3,11 & & & \\
\hline & 21 ve üzeri & 126 & 10,97 & 3,56 & & & \\
\hline
\end{tabular}

Tablo VI'den görüldüğü gibi istismarcı yönetime ilişkin öğretmen görüşleri arasında kıdem değişkenine göre istatistiksel olarak anlamlı fark bulunmaktadır. $\left[\mathrm{F}_{(2,349)}=4,65 ; \mathrm{p}<.05\right]$. Farkın hangi gruplar arasında olduğunu tespit edebilmek için Dunnet $C$ testi incelenmiştir. Sonuçlar kıdem açısından 0-10 yıl arası ile 11-20 yıl arası öğretmenlerin istismarcı yönetime göre görüşlerinin istatistiksel olarak anlamlı bir şekilde farklılaştığını göstermektedir. Buna göre 0-10 yıl arası kıdeme sahip öğretmenler, 11-20 yıl arası öğretmenlere göre istismarcı yönetime ilişkin maddelere daha fazla katılım göstermektedir. Ayrıca 11-20 yıl kıdeme sahip öğretmenler ile 21 yıl ve üzeri kıdeme sahip öğretmenlerin istismarcı yönetime ilişkin görüşleri arasında da istatistiksel olarak anlamlı farklılık bulunmaktadır. 21 yıl ve üzeri kıdeme sahip öğretmenler, 11-20 yıl kıdeme sahip öğretmenlere göre istismarcı yönetime ilişkin maddelere daha fazla katılım göstermektedir. Dolayısıyla sonuçlar göstermektedir ki hem 0-10 yıl arası kıdeme sahip öğretmenler hem de 21 yıl ve üzeri kıdeme sahip öğretmenler, 11-20 yıl arası kıdeme sahip öğretmenlere göre istismarcı yönetim maddelerine daha fazla katılım göstermektedir.

Katılımcıların öç almaya ilişkin görüşleri ise kıdem değişkenine göre öç alma nedenleri $\left[\mathrm{F}_{(2,348)}=2,77\right.$; $\mathrm{p}>.05]$, duygusal tepkiler $\left[\mathrm{F}_{(2,349)}=1,49 ; \mathrm{p}>.05\right]$ ve davranışsal tepkiler $\left[\mathrm{F}_{(2,349)}=, 246 ; \mathrm{p}>.05\right]$ boyutlarında anlamlı fark göstermemektedir.

\section{Okul Türü Değişkenine Göre Öğretmenlerin İstismarcı Yönetim ve Öç Almaya İlişkin Görüşleri}

Katılımcıların istismarcı yönetim ve öç alma davranışına ilişkin görüşlerinin okul türü değişkenine göre farklılaşıp farklılaşmadığı ANOVA testi ile incelenmiş, farkın kaynağı ise Dunnet $C$ testi ile tespit edilmiş ve sonuçlara Tablo VII'de yer verilmiştir.

Tablo VII

Okul Türü Değişkenine Göre ANOVA Testi Sonuçları

\begin{tabular}{|c|c|c|c|c|c|c|c|c|}
\hline & Kategoriler & $\mathbf{N}$ & $\overline{\mathrm{X}}$ & Ss & Sd & F & p & $\begin{array}{c}\text { Anlamlı Fark } \\
\text { (Dunnet C) }\end{array}$ \\
\hline \multirow{3}{*}{$\begin{array}{l}\text { İstismarcı } \\
\text { Yönetim }\end{array}$} & İlkokul & 65 & 16,75 & 3,17 & \multirow{3}{*}{2,354} & \multirow{3}{*}{3,18} & \multirow{3}{*}{.045} & \multirow{3}{*}{$2-3$} \\
\hline & Ortaokul & 82 & 16,21 & 2,24 & & & & \\
\hline & Lise & 210 & 17,37 & 4,16 & & & & \\
\hline \multirow{3}{*}{$\begin{array}{l}\text { Öç Alma } \\
\text { Nedenleri }\end{array}$} & İlkokul & 65 & 15,80 & 7,33 & \multirow{3}{*}{2,353} & \multirow{3}{*}{,459 } & \multirow{3}{*}{.632} & \\
\hline & Ortaokul & 82 & 15,47 & 6,32 & & & & \\
\hline & Lise & 209 & 16,32 & 7,37 & & & & \\
\hline \multirow{3}{*}{$\begin{array}{l}\text { Duygusal } \\
\text { Tepkiler }\end{array}$} & İlkokul & 65 & 15,83 & 5,79 & \multirow{3}{*}{2,354} & \multirow{3}{*}{1,80} & \multirow{3}{*}{.165} & \\
\hline & Ortaokul & 82 & 14,12 & 6,15 & & & & \\
\hline & Lise & 210 & 14,34 & 5,99 & & & & \\
\hline \multirow{3}{*}{$\begin{array}{l}\text { Davranışsal } \\
\text { Tepkiler }\end{array}$} & İlkokul & 65 & 11,00 & 3,44 & \multirow{3}{*}{2,354} & \multirow{3}{*}{ 178 } & \multirow{3}{*}{.837} & \\
\hline & Ortaokul & 82 & 10,69 & 3,08 & & & & \\
\hline & Lise & 210 & 10,88 & 3,16 & & & & \\
\hline
\end{tabular}

Tablo VI'ye göre katılımcıların görüşleri istismarcı yönetime ilişkin okul türü değişkenine göre anlamlı bir fark göstermektedir $\left[\mathrm{F}_{(2,354)}=3,18 ; \mathrm{p}<.05\right]$. Farkın kaynağını bulmaya yönelik yapılan Dunnet $\mathrm{C}$ testi sonucuna göre liselerde çalışan öğretmenler ortaokullarda çalışan öğretmenlere göre istismarcı yönetime ilişkin ifadelere daha çok katılmaktadır. Katılımcıların görüşleri, öç alma nedenleri $\left[\mathrm{F}_{(2,353)=}, 459 ; \mathrm{p}>.05\right]$, duygusal tepkiler $\left[\mathrm{F}_{(2,354)}=1,80 ; \mathrm{p}>.05\right]$ ve davranışsal tepkiler $\left[\mathrm{F}_{(2,354)}=, 178 ; \mathrm{p}>.05\right]$ boyutlarında okul türü değişkeni açısından istatistiksel olarak anlamlı fark göstermemektedir.

\section{Branş Değişkenine Göre Öğretmenlerin İstismarcı Yönetim ve Öç Almaya İlişkin Görüşleri}

Katılımcıların istismarcı yönetim ve öç alma davranışına ilişkin görüşlerinin branş değişkenine göre farklılaşıp farklılaşmadığı ANOVA ile incelenmiş ve sonuçlar Tablo VIII'de verilmiştir. 
Tablo VIII

Branş Değişkenine Göre ANOVA sonuçları

\begin{tabular}{|c|c|c|c|c|c|c|c|}
\hline & Kategoriler & $\mathbf{N}$ & $\bar{X}$ & Ss & sd & F & p \\
\hline \multirow{6}{*}{$\begin{array}{l}\text { İstismarcı } \\
\text { Yönetim }\end{array}$} & 1.sınıf öğretmeni & 57 & 16,66 & 3,04 & \multirow{6}{*}{5,348} & \multirow{6}{*}{1,94} & \multirow{6}{*}{.087} \\
\hline & 2.yabancı dil & 49 & 18,42 & 4,65 & & & \\
\hline & 3.Türkçe & 38 & 16,81 & 2,45 & & & \\
\hline & 4.Fen-Matematik & 89 & 16,60 & 3,02 & & & \\
\hline & 5.sözel & 39 & 16,58 & 3,85 & & & \\
\hline & 6.diğer & 82 & 17,09 & 4,25 & & & \\
\hline \multirow{6}{*}{$\begin{array}{l}\text { Öç Alma } \\
\text { Nedenleri }\end{array}$} & 1.sınıf öğretmeni & 57 & 15,89 & 7,55 & \multirow{6}{*}{5,347} & \multirow{6}{*}{ 182 } & \multirow{6}{*}{.969} \\
\hline & 2.yabancı dil & 49 & 15,93 & 7,06 & & & \\
\hline & 3.Türkçe & 38 & 15,50 & 5,04 & & & \\
\hline & 4.Fen-Matematik & 89 & 16,62 & 8,15 & & & \\
\hline & 5.sözel & 39 & 15,74 & 6,65 & & & \\
\hline & 6.diğer & 81 & 16,11 & 6,93 & & & \\
\hline \multirow{6}{*}{ Duygusal Tepkiler } & 1.sınıf öğretmeni & 57 & 16,07 & 5,69 & \multirow{6}{*}{5,348} & \multirow{6}{*}{1,96} & \multirow{6}{*}{.083} \\
\hline & 2.yabancı dil & 49 & 14,38 & 5,44 & & & \\
\hline & 3.Türkçe & 38 & 15,52 & 5,98 & & & \\
\hline & 4.Fen-Matematik & 89 & 13,46 & 6,31 & & & \\
\hline & 5.sözel & 39 & 13,30 & 5,92 & & & \\
\hline & 6.diğer & 82 & 14,96 & 6,02 & & & \\
\hline \multirow{6}{*}{$\begin{array}{l}\text { Davranışsal } \\
\text { Tepkiler }\end{array}$} & 1.sınıf öğretmeni & 57 & 10,96 & 3,36 & \multirow{6}{*}{5,348} & \multirow{6}{*}{, 578} & \multirow{6}{*}{.717} \\
\hline & 2.yabancı dil & 49 & 10,87 & 2,76 & & & \\
\hline & 3.Türkçe & 38 & 11,26 & 2,95 & & & \\
\hline & 4.Fen-Matematik & 89 & 10,48 & 2,92 & & & \\
\hline & 5.sözel & 39 & 10,64 & 3,66 & & & \\
\hline & 6.diğer & 82 & 11,18 & 3,50 & & & \\
\hline
\end{tabular}

Tablo VIII'e göre katılımcıların görüşleri branş değişkenine göre istismarcı yönetim $\left[\mathrm{F}_{(5,348)}=1,94 ; \mathrm{p}>.05\right]$,

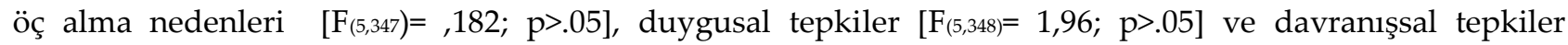
$\left[\mathrm{F}_{(5,348)}=, 578 ; \mathrm{p}>.05\right]$ boyutlarında anlamlı fark göstermemektedir.

\section{Öğretmenlerin İstismarcı Yönetim ve Öç Almaya Davranışları Arasındaki İlişki}

Katılımcıların istismarcı yönetim ve öç alma davranışları arasında ilişki olup olmadığı korelasyon analizi ile incelenmiştir.

Tablo IX

İstismarcı Yönetim ve Öç alma Davranışı Arasındaki İlişkiye İlişkin Korelasyon Sonuçları

\begin{tabular}{llccc}
\hline Boyutlar & & Öç Alma Nedenleri & Duygusal Tepkiler & Davranışsal Tepkiler \\
\hline \multirow{3}{*}{ İstismarcı Yönetim } & $\mathrm{r}$ & .257 & .022 & .264 \\
& $\mathrm{p}$ & .000 & .679 & .000 \\
& $\mathrm{~N}$ & 360 & 361 & 361 \\
\hline
\end{tabular}

Tablo IX incelendiğinde katılımcıların istismarcı yönetime ilişkin görüşleri ile öç alma nedenlerine (r= .257) ve davranışsal tepkilere ( $\mathrm{r}=.264)$ ilişkin görüşleri arasında istatistiksel olarak anlamlı ve pozitif yönde düşük düzeyde bir ilişki olduğu görülmektedir. Determinasyon katsayılarına bakıldığında $\left(\mathrm{r}^{2}=0.06 ; \mathrm{r}^{2}=.007\right)$ öç alma nedenlerine ilişkin toplam varyansın \%6'sının ve davranışsal tepkilere ilişkin toplam varyansın \%7'sinin istismarcı yönetimden kaynaklandığı söylenebilir. Başka bir deyişle katılımcıların istismarcı yönetime ilişkin algıları arttıkça daha fazla öç almak istemekte ve bu isteklerini daha fazla davranışa yansitmaktadir.

\section{Sonuç ve Tartışma}

Eğitimde araştırmacılar çoğunlukla okuldaki istismarcı gücün doğası ve türleriyle ilgilenmektedirler (Blase ve Blase, 2002; De Wet, 2013). Ancak bu araştırma eğitim örgütlerinde istismarcı yönetimin öç alma 
davranışına yol açıp açmadığına odaklanmıştır. Okul ortamında okul müdürü tarafından öğretmenlere yönelik istismarcı yönetim davranışında bulunulması sık görülen bir durum değildir. Benzer sonuca Demirkasımoğlu (2018) da eğitim örgütlerinde yaptığı araştırmasıyla ulaşmıştır. Bu araştırmada katılımcıların en çok işaretledikleri istismarcı yönetim ifadeleri, "Yöneticim işteki çabalarımı takdir etmez.", "Yöneticim sözünde durmaz." ve "Yöneticim bana küser." şeklindeyken, Demirkasımoğlu'nun (2018) araştırmasında katılımcllar en çok "Yöneticim sözünde durmaz.", "Yöneticim benim hakkımda olumsuz yorumlarda bulunur." ve "Yöneticim bana yalan söyler." şeklindedir. Her iki araştırmada da "Yöneticim sözünde durmaz." ifadesinin katılımcıların en çok katıldıkları ifadeler arasında olması, öğretmenlerin yöneticileri ile ilişkilerinde güven sorunu yaşıyor olabileceklerini veya aralarında iletişim problemlerinin olabileceğini akla getirmektedir.

Tepper'in (2007) istismarcı yönetim algısında çalışan özelliklerinin incelenmesi gerektiğine ilişkin söylemiyle paralel olarak bu araştırmada öğretmenlerin görüşleri cinsiyet, kıdem, okul türü değişkenleri açısından incelenmiştir. Buna göre, araştırmaya katılan öğretmenlerin istismarcı yönetime ilişkin görüşleri, cinsiyet, kıdem, okul türü değişkenlerine göre istatistiksel olarak anlamlı bir şekilde değişmektedir. Araştırma bulgularına göre erkek öğretmenler istismarcı yönetime ilişkin ifadelere daha çok katılmışlardır. Bu durum geleneksel cinsiyet rollerinden hareket ederek Restubog, Scott ve Zagenczyk (2011)'in, erkeklerin kadınlara nazaran sinirli davranma eğilimlerinin olması ve iş yaşamında da bu şekilde davranmaları varsayımını destekler niteliktedir. Öte yandan kadınlar, ağladıklarını ya da arkadaşlarından veya diğer yetişkinlerden yardım istediklerini, dolayısıyla daha fazla sosyal desteğe eriştiklerini erkeklere nazaran daha fazla belirtmektedirler (Zhang ve Bednall, 2016). Aldıkları bu sosyal desteğin sonucu olarak kadınlar istismarcı yönetim ifadelerine daha az katılmış olabilirler. Öte yandan Tunceli ili özel idaresinde çalışan 35 personel ile gerçekleştirilen araştırmada, kurum çalışanlarının istismarcı yönetime ilişkin algılarının cinsiyete göre farklılık göstermediği bulunmuştur (Yıldırım ve Benlier, 2017). Benzer biçimde Demirkasımoğlu (2018) araştırmasında, kadın ve erkeklerin algıladıkları istismarcı yönetim düzeyleri arasında anlamlı fark bulmamıştır. Bir başka araştırmada ise kadın katılımcılar, olumlu ve istismarcı senaryo tiplerinde erkek katılımcılara kıyasla daha yüksek istismar algılamışlardır (Taftaf, 2018).

Araştırma bulgularına göre, 0-10 yıl arası kıdeme sahip öğretmenler ve 21 yıl ve üzeri kıdeme sahip öğretmenler, 11-20 yıl arası kıdeme sahip öğretmenlere göre istismarc1 yönetim ölçeğinin ifadelerine daha fazla katılım göstermektedir. Zhang ve Bednall (2016) bu durumu, kıdemi az olan çalışanların, daha kıdemli çalışanlara kıyasla istismarcı yönetime maruz kalmaya daha açık olmalarıyla açıklamaktadırlar. Öte yandan ast üstüyle uzun bir süreden beri çalışıyorsa, üstün davranışlarına alışır ve muğlak davranışlarını istismarcı olarak yorumlamama eğilimindedir. Bu durum, 11-20 yıl arası kıdeme sahip öğretmenlere ilişkin bulguyu açıklamaktadır. Diğer yandan, Conway ve Coyle-Shapiro (2012)'ya göre kıdemli çalışanlar, daha fazla sosyal destek alma şansına sahiptirler ve bu durum onların istismara maruz kalmaları olasılığını düşürür. Ancak bu ifade, araştırma verileriyle uyumlu değildir. Bu durum, kültürler arası farklılıktan kaynaklanıyor olabilir. Artık mesleğinde son dönemi yaşayan öğretmenler, daha fazla deneyim kazanıp profesyonelleştikçe istismarcı yönetime maruz kaldıklarını kolaylıkla fark ediyor olabilirler.

Araştırma bulgularına göre liselerde çalışan öğretmenler, ilkokullarda ve ortaokullarda çalışan öğretmenlere göre istismarcı yönetime ilişkin ifadelere daha çok katılmaktadır. Bu durumun nedeni, ortaöğretim kurumlarındaki yöneticilerin farklı okul iklimine sahip olması olabilir. İleride yapılacak çalışmalarda bu farklılığın araştırılması uygun olacaktır. Böyle bir farkın neden çıktığını belirlemek için nitel araştırma yapılabilir.

Araştırma bulgularına göre, örgütsel öç alma ölçeğinin davranışsal tepkiler boyutundaki ifadelere erkek öğretmenler daha fazla katılım göstermektedir. Demirkasımoğlu (2018) araştırmasında, istimarcı yönetime maruz kaldıklarında erkek öğretmenlerin, kadın öğretmenlerden daha fazla geri çekilme ve intikam alma davranışları gösterdikleri sonucuna ulaşmıştır. Bir başka çalışmada Nayir (2015) öğretmen adaylarının görüşlerini cinsiyet değişkenine göre incelemiş ve erkek öğretmen adaylarının kadınlara göre öç alma davranışına daha olumlu baktığını belirlemiştir. Ancak aksi duruma işaret eden çalışmalara da alanyazında rastlanmaktadır. Örneğin; güç, acıya tahammül etmek ve saldırganlık, erkekliği yansıtmak becerisinde temsil 
edilmektedir ve Filipinli erkeklerden toplumsal olarak beklenen budur. Bu kültürel unsurlar göz önüne alınırsa, Filipinli çalışanlar istismarcı yönetimin hedefi haline geldiklerinde, ast üst ilişkisine özgü güç asimetrisini kabul ettikleri ve buna saygı duydukları için, üstlerine karşı öç alma davranışında bulunmaları daha az olasidır (Restubog, Scott ve Zagenczyk, 2011).

Araştırma bulgularına göre istismarcı yönetim ile öç alma nedenleri ve davranışsal tepkiler arasında pozitif ilişki vardır. Buna göre katılımcılar istismarcı yönetime maruz kaldıkça öç almak istemekte ve öç almak için harekete geçmektedirler. Belirtilen bulgu öğretmenler öç alma davranışı sergiledikçe yöneticiler de istismarcı yönetim davranışı göstermektedir şeklinde de yorumlanabilir. Bu bulgu, benzer konularda yapılmış araştırma bulgularıyla desteklenebilir. Örneğin, Lian ve arkadaşlarının (2014) araştırmasında, istismarcı yönetim ile üste yöneltilen saldırganlık arasında pozitif ilişki olduğu sonucuna ulaşmışlardır. Araştırmalarının bulgularına göre, istismarcı yöneticiye yöneltilen intikam davranışı, ya astın kendini kontrol becerisindeki eksiklikten ya da kendini kontrol edebilme motivasyonunu sağlayacak şartların eksikliğinden kaynaklanıyor olabilir. Öte yandan düşmanlığın da intikamcı davranışı arttırdığı sözü edilen araştırma bulguları ile belirlenmiştir. Ishaq ve Shamsher (2016)'in çalışmasının bulgularına göre, psikolojik sözleşmenin ihlali ile iş yerinde örgüte yönelik sapkın davranışlar arasında pozitif ve anlamlı ilişki vardır. Üçok ve Turgut'un (2014) yaptığı araştırmada ise, istismarcı yönetici davranışının örgüte ve çalışanlara yönelik sapkın davranış ile pozitif yönde ve anlamlı ilişkisinin bulunduğu belirlenmiştir. Belirtilen araştırmalar, sapkın davranışların istismarcı yönetimin olumsuz sonuçları arasında kabul edilmesi nedeniyle önemlidir. Bu araştırma bulgularıyla paralel şekilde, Demirkasımoğlu'nun (2018) araştırmasında yöneticinin istismarcı davranışıla geri çekilme ve öç alma arasında düşük düzeyli pozitif ilişki bulunmaktadır.

Alanyazında ileri sürülen görüşlerden, benzer konularda yapılmış çalışmalardan ve bu araştırma bulgularından yola çıkarak bireylerin davranışlarının sonuçları konusunda eğitim verilmesiyle, istismarcı yönetim ve öç alma davranışını azaltabilmenin mümkün olduğu düşünülebilir ve çalışanları geliştirecek eğitimlerin düzenli yapılması önerilebilir. Bunun yanı sıra yöneticilerin insan ilişkileri yaklaşımına uygun davranışlar sergilemeleri, iş yerinde tutarlı ve adil davranarak güven ortamı oluşturmaları öç alma davranışının yaratabileceği sorunları çözmeye yardımcı olabilir. Öte yandan iş yeri kurallarının güçlendirilmesi de istismarcı yönetim ve öç alma davranışlarının azalmasında katkı sağlayabilir. Bunun için iş yeri kurallarını ihlal edenler için cezalar öngörülmesi ya da çalışan lehine olabilecek resmi müdahalelerde bulunulması öneri olarak düşünülebilir. Öte yandan istismarcı yönetici davranışının çok sık ortaya çıkmadığı bu araştırmada katılanlar tarafından belirtilse de, ortaya çıkması halinde öğretmenlerin istismarcı yönetim davranışıyla nasıl başa çıktıklarını açıklayan çalışmaların yapılmasının yararlı olacağı düşünülmektedir. Ayrıca, istismarcı yönetim ve öç alma Türkiye'de yeni ele alınan bir kavram olması sebebiyle bu kavramın örgütsel adalet, örgütsel vatandaşlık, örgütsel bağl1lı, örgütsel destek algısı, iş doyumu gibi örgütsel kavramlarla incelenmesinin de alanyazına katkı sunacağı düşünülmektedir.

\section{Kaynaklar}

Anderson, G. (1990). Fundamentals of educational research. The Farmer Press: London.

Aquino, K., Tripp, T. M. ve Bies, R. J. (2006). Getting even or moving on? Power, procedural justice, and types of offense as predictors of revenge, forgiveness, reconciliation, and avoidance in organizations. Journal of Applied Psychology, 91(3), 653-668.

Aryee, S., Chen, Z. X., Sun, L. Y. ve Debrah, Y. A. (2007). Antecedents and outcomes of abusive supervision: Test of a trickle-down model. Journal of Applied Psychology, 92(1), 191-201.

Başaran, İ. E. ve Çınkır, Ş. (2013). Türk eğitim sistemi ve okul yönetimi. Ankara: Siyasal Kitabevi.

Berkowitz, L. (1989). Frustration-aggression hypothesis: Examination and reformulation. Psychological Bulletin, 106(1), 59-73.

Bies, R. J. (2001). Interactional (in) justice: The sacred and the profane. J. Greenberg ve R. Cropanzano (Ed.), Advances in organizational behavior (s. 89-118) içinde. Stanford, CA: Stanford University Press. 
Bies, R. J. ve Tripp, T. M. (1998). Two faces of the power-less: Coping with tyranny. R. M. Kramer ve M. A. Neale (Ed.), Power and influence in organizations (s. 203-219) içinde. Thousand Oaks, CA: Sage.

Bies, R. J. ve Tripp, T. M. (2005). The study of revenge in the workplace: conceptual, ideological and empirical issues. S. Fox ve P. E. Spector (Ed.), Counter productive workbehavior: Investigations of actors and targets (s. 6581) içinde. Washington, DC, US: American Psychological Association.

Blase, J. ve Blase, J. (2002). The dark side of leadership: Teacher perspectives of principal mistreatment. Educational Administration Quarterly, 38(5), 671-727.

Conway, N. ve Coyle-Shapiro, J. A. M. (2012). The reciprocal relationship between psychological contract fulfilment and employee performance and the moderating role of perceived organizational support and tenure. Journal of Occupational and Organizational Psychology, 85(2), 277-299.

de Quervain, D. J., Fischbacher, U., Treyer, V., Schellhammer, M., Schnyder, U. ve Fehr, E. (2004). The neural basis of altruistic punishment. Science, 305(5688), 1254-1258.

De Wet, C. (2013). The abusive school principal: A South African case study. Bulgarian Comparative Education Society, 76, 223-230.

Demirkasımoğlu, N. (2018). The role of abusive supervision in predicting teachers' withdrawal and revenge responses. Cultura y Educación, 30(4), 693-729.

Fraenkel, J. R. ve Wallen, N. E. (2006). How to design and evaluate research in education (6. bs.). New York: McGraw Hill.

Fromm, E. (1973). The anatomy of human destructiveness. Greenwich, CT: Fawcett Crest.

Harvey, P., Stoner, J., Hochwarter, W. ve Kacmar, C. (2007). Coping with abusive supervision: The neutralizing effects of ingratiation and positive affect on negative employee outcomes. The Leadership Quarterly, 18(3), 264-280.

Inness, M., Barling, J. ve Turner, N. (2005). Understanding supervisor targeted aggression: A within-person, between jobs design. Journal of Applied Psychology, 90(4), 731-739.

Ishaq, H. M. ve Shamsher, Q. (2016). Effect of breach of psychological contracts on workplace deviant behaviors with the moderating role of revenge attitude and self-control. Pakistan Journal of Commerce and Social Sciences, 10(1), 69-83.

Leith, K. P. ve Baumeister, R. F. (1996). Why do bad moods increase self-defeating behavior? Emotion, risk taking, and self-regulation. Journal of Personality and Social Psychology, 71(6), 1250-1267.

Lian, H., Brown D. J., Ferris D. L., Liang L.H., Keeping, L. M. ve Morrison, R. (2014). Abusive supervision and retaliation: A self-control framework. Academy of Management Journal, 57(1), 116-139.

Liu, J., Kwan, H. K., Wu, L. ve Wu, W. (2010). Abusive supervision and subordinate supervisor-directed deviance: The moderating role of traditional values and the mediating role of revenge cognitions. Journal of Occupational and Organizational Psychology, 83(4), 835-856.

Nayir, K. F. (2015). Öğretmen adaylarının öç alma davranışına ilişkin görüşleri. Turkish Studies International, $10 / 11,1205-1216$.

Nayir, K. F. (2016). Örgütsel öç alma ölçeğinin geliştirilmesi ve öğretmenlerin örgütsel öç alma davranışına ilişkin görüşlerinin incelenmesi. Uluslararası Online Ĕ̆itim Bilimleri Dergisi, 8(3), 128 -142.

Neuman, J. H. ve Baron, R. A. (1996). Aggression in the workplace. R. Giacalone ve J. Greenberg (Ed.), Antisocial behavior in organizations (s. 37-67) içinde. Thousand Oaks, CA: Sage.

Martinko, M. J., Harvey P., Brees J. R. ve Mackey, J. (2013). A review of abusive supervision research. Journal of Organizational Behavior, 34(S1), 120-137. 
Mount, M. K., Ilies, R. ve Johnson, E. (2006). Relationship of personality traits and counterproductive work behaviors: The mediating effects of job satisfaction. Personnel Psychology, 59(3), 591-622.

Park, H., Hoobler, J.M., Wu, J., Liden, R.C. Hu, J. ve Wilson, M.S. (2017). Abusive supervision and employee deviance: A multifoci justice perspective. Journal of Business Ethics. 1-19. https://doi.org/10.1007/s10551017-3749-2.

Restubog, S. L. D., Scott, K. L. ve Zagenczyk, T. J. (2011). When distress hits home: The role of contextual factors and psychological distress in predicting employees' responses to abusive supervision. Journal of Applied Psychology, 96(4), 713-729.

Robinson, S. L. ve Bennett, R. J. (1995) A typology of deviant workplace behaviours: A multidimensional scaling study. Academy of Management Journal, 38(2), 555-572.

Stuckless, N. ve Goranson, R. (1992). The vengeance scale: Development of a measure of attitudes toward revenge. Journal of Social Behavior and Personality, 7(1), 25-42.

Şener, E. ve Erdem, R. (2014, Mayıs). Akademik örgütlerde intikamın şekil ve belirleyicilerine ilişkin nitel bir çalışma. 22. Ulusal Yönetim ve Organizasyon Kongresi, Konya, Türkiye.

Taftaf, S. (2018). Examining the dark side of Leadership: The role of gender on the perception of abusive supervision. (Yayımlanmamış yüksek lisans tezi). Ortadoğu Teknik Üniversitesi, Ankara.

Tatarlar, C. ve Güneri-Çangarlı B. (2014, Mayıs). Madalyonun iki yüzü: Örgütsel intikam davranışlarında yöneten ve yönetilen. 22. Ulusal Yönetim ve Organizasyon Kongresi, Konya, Türkiye.

Tepper, B. J. (2000). Consequences of abusive supervision. Academy of Management Journal, 43(2), 178-190.

Tepper, B. J. (2007). Abusive supervision in work organizations: Review synthesis, and research agenda. Journal of Management, 33(3), 261-289.

Tepper, B. J., Carr, J. C., Breaux, D. M., Geider, S., Hu, C. ve Hua, W. (2009). Abusive supervision, intentions to quit, and employees' workplace deviance: A power/ dependence analysis. Organizational Behavior and Human Decision Processes, 109(2), 156-167.

Üçok, D. ve Turgut, T. (2014). İstismarcı yönetici davranışının işyerindeki sapkın davranışlar üzerindeki rolü. Eskişehir Osmangazi Üniversitesi İ̈BF Dergisi, 9(3), 163-179.

Ülbeği, G. D., Özgen, H. M. ve Özgen, H. (2014). Türkiye'de istismarci yönetim ölçeğinin uyarlaması: Güvenirlik ve geçerlik analizi. Çukurova Üniversitesi Sosyal Bilimler Enstitüsü Dergisi, 23(1), 1-12.

Yıldırım, N. ve Benlier, O. C. (2017). İstismarci yönetici algısının işten ayrılma niyeti üzerine etkisi Tunceli ili kamu kurumunda araştırma. Uluslararası Sosyal Araştırmalar Dergisi, 10(48), 679-683.

Zellars, K. L., Tepper, B. J. ve Duffy, M. K. (2002). Abusive supervision and subordinates' organizational citizenship behavior. Journal of Applied Psychology, 87(6), 1068-1076.

Zhang, Y. ve Bednall, T. C. (2016). Antecedents of abusive supervision: A meta-analytic review. Journal of Business Ethics, 139(3), 455-471. 


\section{EXTENDED ABSTRACT}

\section{Introduction}

"Abusive management is the perceptions of the subordinates regarding the verbal and non-verbal hostile behavior of the managers, which does not consist of physical contact" (Tepper, 2000, pp. 178). As many researchers have pointed out, managers have power over their subordinates as a result of which the abusive manager can take actions such as not giving the reward that the subordinates may deserve, punishing them or taking revenge (Aquino, Tripp \& Bies, 2006; Tepper et al., 2009). Besides, research has shown that there is a relationship between abusive management and subordinates' revenge behavior directed to the manager (Inness, Barling \&Turner, 2005; Liu, Kwan, Wu \& Wu, 2010; Tepper et al., 2009). Revenge is a planned act in order to harm someone who acts in an unfair or a misconduct manner. Revenge is a feeling that negatively affects individuals.

The aim of this research was to determine the relationship between abuse management and revenge behavior in educational organizations. For this purpose, the following questions were asked:

1) What is the view of teachers about the abusive management?

2) What is the view of teachers about the behavior of revenge?

3) Do teachers' views on abusive management differentiate significantly according to gender, seniority, branch and type of school variables?

4) Do teachers' views on the behavior of revenge differentiate significantly according to gender, seniority, branch and type of school variables?

5) Is there a statistically significant relationship between the teachers' views on the revenge behavior and the abusive management?

\section{Method}

In this research, which aimed to determine the relationship between abusive management and revenge behavior in educational organizations, correlational survey model was used. The Abusive Management scale, developed by Tepper (2000) and adapted to Turkish by Ülbeği, Mimaroğlu Özgen and Özgen (2014), and the Organizational Revenge Scale developed by Nayir (2016) were used in this study. The data obtained from the surveys and applied to 361 teachers working in public schools in Ankara city center were analyzed.

The data were analyzed with descriptive statistics, DFA, t-test, ANOVA and Pearson correlation. In the analysis of data, t-test was used for gender and educational status variables; ANOVA was used for the variables of seniority and school type; and correlation analysis was used to reveal the relationship between abusive management and revenge behavior.

\section{Results}

According to the results, "My manager doesn't give me credit for jobs requiring a lot of effort." is the most agreed item of the abusive management scale by teachers. The most agreed item of the "reasons for taking revenge factor" was "I want to take revenge when I am blocked or stopped to use my personal rights arbitrarily."; on the other hand, the mostly agreed item of the "emotional reactions" factor was "I think revenge is a primitive behavior.", and lastly the mostly agreed item of the factor called as "behavioral reactions" was "When I want to take revenge, I report the person who caused it to the superior institutions.".

The findings of the research showed that, there was a significant difference between the views of the participants about the abusive management and the behavioral reactions factor of the organizational revenge according to the gender variable. In both factors, male teachers were more likely to agree with the statements related to abusive management than female teachers. There was a significant difference between the views on the reasons for taking revenge and behavioral reactions factors according to the educational level variable. There was a statistically significant difference between the views of the teachers regarding the abusive management according to seniority variable. Teachers with experience between $0-10$ years and teachers with experience of 21 years or more agreed with abusive management items more than the teachers who had experience between 11-20 years. Participants' opinions related to the abusive management were significantly differed according to the school type variable. Teachers working at high schools were more likely to agree 
with the items of abusive management scale than teachers working in secondary schools. The views of the participants were not significantly different according to the branch variable in terms of abusive management, the reasons for the revenge seeking, emotional reactions, and behavioral reactions factors. It was found that there was a low positive and significant relationship between the views of the participants on abusive management and their views on the reasons for taking revenge and behavioral reactions.

\section{Conclusion}

According to the research findings, there was a positive relationship between abusive management and the reasons for taking revenge and behavioral reactions. According to this finding, it is possible to say that, when the participants are exposed to abusive management, they want to take revenge and attempt to take revenge. This finding can be supported by the research findings on similar subjects. For example, Lian et al. (2014) have concluded that there is a positive relationship between abusive management and aggression directed to the manager. Üçok and Turgut (2014) have found that there is a positive significant relationship between abusive behavior of the manager and the deviant behavior towards the employees. In parallel with the findings of this research, Demirkasımoğlu's (2018) research has shown that there is a low positive relationship between the abusive behavior of the manager and withdrawal and revenge behaviors of teachers. Although it is stated by the participants in this research that the behavior of the abusive management is not seen very often, it may be suggested that it would be useful to do new studies explaining how the teachers cope with the abusive management behavior. 